This is the peer reviewed version of the following article: Glencross B, Blyth $D$, Cheers S, Bourne N, Wade N, Irvin S. A compendium of raw material digestibilities for barramundi, Lates calcarifer. Aquacult Nutr. 2017;23:10551064, which has been published in final form at

https://doi.org/10.1111/anu.12473. This article may be used for noncommercial purposes in accordance With Wiley Terms and Conditions for selfarchiving. 
4 Brett Glencross ${ }^{1,3}$, David Blyth ${ }^{2}$, Susan Cheers ${ }^{1}$, Nicholas Bourne ${ }^{1}$, Nick Wade ${ }^{1}$, Simon Irvin ${ }^{2}$ 5

6

1. CSIRO Aquaculture, PO Box 2583, Brisbane, QLD 4001, Australia

2. CSIRO Aquaculture, 141 North St, Woorim, QLD 4706, Australia

3. Present address: Institute of Aquaculture, Stirling University, FK9 4LA Stirling, United Kingdom

Correspondence to: Brett Glencross

(e) b.d.glencross@stir.ac.uk

15

16

17 Keywords: Asian seabass, ingredients, digestibility, plant proteins, animal by-products 18

19 To be submitted to: Aquaculture Nutrition 
1 Abstract

2

3 A series of experiments were conducted to examine the nutrient and energy digestibility of a suite

4 of diets and specific test raw materials when fed to juvenile (179g to $439 \mathrm{~g}$ ) barramundi, Lates

5 calcarifer. Each of the diets was prepared using a twin-screw extruder to mimic modern aquafeed

6 manufacturing processes. Each of the diets were fed to juvenile barramundi for a minimum of a

7 week to allow acclimation to the diet before the faeces were collected using stripping methods. A

8 broad range of digestible nutrient and energy values among the different raw materials were

9 observed, with protein digestibilities ranging from $36 \%$ to $106 \%$, and energy digestibilities ranging

10 from $36 \%$ to $93 \%$. This range in nutritional values of the different raw materials provides

11 substantial utility in allowing the formulation of diets on a digestible nutrient and energy basis

12 across the Asia Pacific region. These results also provide critical data to help underpin the replacement of both fishmeal and fishoil in barramundi diets. 
Introduction

Aquaculture has long been perceived to be reliant on fishmeal as a protein source and fishoil as a lipid source (Tacon \& Metian, 2008). However, over the recent decades there have been a multitude of studies examining a range of different raw materials that have potential application in reducing the reliance on these marine fishery resources as feed inputs for aquaculture (reviewed by Gatlin et al., 2007; reviewed by Glencross 2009). In order to reduce this reliance, it is critical to assess alternative raw materials. A series of key knowledge elements is recognised as being required to enable the effective utilisation of alternative raw materials by the feed production sector. Those being the characterisation of the raw material, the determination of its digestible nutrient and energy value, before assessing the palatability and utilisation value parameters (Glencross et al., 2007).

For barramundi (Lates calcarifer), there has been a significant volume of work examining elements of the raw material assessment process (Glencross et al., 2013; Blyth et al., 2015). Much of this work has focussed on either rendered animal meals (Williams et al., 2001; 2003a; 2003b; Glencross, 2011; Glencross et al., 2011) or feed grains (Glencross, 2011; Glencross et al., 2011; 2012). In both cases it has been demonstrated that either rendered animal meals or feed grains can replace substantial amounts of fishmeal in diets for this species. However, it has also been suggested that a critical threshold of around $15 \%$ fishmeal was pertinent to barramundi to induce adequate feed intake when fed a diet balanced for digestible protein, energy and amino acids using a plant protein concentrate as the alternative (Glencross et al., 2011; Glencross et al., 2016).

There has been somewhat less work on examining fishoil replacement in feeds for barramundi, though there has been much work done on other fish species (reviewed by Glencross, 2009). Despite this there have been some recent studies that have demonstrated that it has been possible to replace virtually all the fish oil in barramundi diets, so long as high inclusions of fishmeal were present and a minimum level of LC-PUFA maintained (Alhazzaa et al., 2011; Salini et al., 2015).

However, in order to progress the effective replacement of fishmeal and fish oils in feeds for barramundi it is essential that a compendium of raw material digestibilities for this species is assembled, similar that that has been done for Atlantic salmon (Aslaksen et al., 2007). Therefore, the present study was undertaken to determine the digestible value of suite of raw materials and also compile this data with other data from the literature into a single compendium. 
The experiment design to determine the digestibilities of a series of test ingredients was based on the diet substitution approach (reviewed by Glencross et al., 2007), whereby a basal diet formulation to which each test ingredient was added at $30 \%$ by weight to a reciprocal $70 \%$ weight of the basal diet formulation. For each experiment a single batch of basal mash was formulated and prepared (Table 1).

To compare and contrast the data from this series of experiments a literature search was also undertaken of all public domain (peer-reviewed journal literature, reports, etc) barramundi digestibility data.

\section{Diet preparation}

A laboratory-scale, twin-screw extruder (APV MFP19:25; APV-Baker, Peterborough, United Kingdom), with intermeshing, co-rotating screws was used to process all diets in this study. Each diet was extruded using the same processing parameters (Glencross et al., 2012). Water was peristaltically pumped (Watson-Marlow 504U, Falmouth, England) into the barrel at between 25 and $36 \mathrm{~mL} \mathrm{~min}^{-1}$. Water addition was varied among diets based on maximising the expansion potential of each diet, with measurements taken during initial running phases with incremental variations in water addition and measurement of the expansion using vernier callipers (TradeToolsDirect, Ormeau, Australia). A $4 \mathrm{~mm} \varnothing$ die was used for all diets and pellets were cut into 5 to $6 \mathrm{~mm}$ lengths using a four-bladed variable speed cutter and collected on large aluminium oven trays ( $650 \times 450 \times 25 \mathrm{~mm}$, length $\mathrm{x}$ width $\mathrm{x}$ depth) before being dried at $65^{\circ} \mathrm{C}$ for $12 \mathrm{~h}$. All other operational parameters and extrusion configurations were maintained constant for each of the diets. For some diets (the oil specific ones) the specified oil allocation was vacuum infused into the dried pellets using the methods reported in Glencross et al. (2012). 
Barramundi handling and faecal collection

Juvenile barramundi were kept in an experimental tank array ( $24 \times 300 \mathrm{~L}$ or $24 \times 1000 \mathrm{~L})$ supplied with flow-through seawater (salinity $=35 \mathrm{PSU}$; dissolved oxygen $\sim 6.0 \mathrm{mg} \mathrm{L}^{-1}$ ) of $\sim 30^{\circ} \mathrm{C}$ at a rate of about $4 \mathrm{~L} \mathrm{~min}^{-1}$. Each of the tanks were stocked with 20 fish. The specific fish sizes and environmental conditions used in each trial are presented in Table 2. Treatments were randomly assigned amongst the 24 tanks, with each treatment having four replicates, but the experiment being conducted over two block events (duplicates of each treatment were used within each of two blocked events) to achieve this level of replication. The same batch of fish was used for both blocks, but a complete randomised design was applied to each block to ensure experimental validity. The fish were allowed to acclimatise to their allocated dietary treatment for at least seven days before faecal collection commenced (Blyth et al., 2015).

For faecal collection the barramundi were hand fed their respective diets once daily to apparent satiation based on their response to an offering of 3 meals between 0800 and $0900 \mathrm{~h}$. Faeces were then collected the same afternoon $(1500-1630)$ from each fish following anaesthesia using AQUI-S $\mathrm{S}^{\mathrm{TM}}\left(0.02 \mathrm{~mL} \mathrm{~L}^{-1}\right)$ using stripping techniques based on those reported by Blyth et al. (2015). Fish were not stripped on consecutive days in order to minimise stress on the animal (as determined by loss of appetite and physical damage, of which none was observed) and to maximise feed intake prior to faecal collection. Faecal samples from different days were pooled within tank, and kept frozen at $-20^{\circ} \mathrm{C}$ before being freeze-dried in preparation for analysis.

\section{Chemical and digestibility analysis}

The chemical analyses undertaken varied from experiment to experiment subject to the amount of faecal sample that was available. Dry matter content was calculated following oven drying at 105 으 for $24 \mathrm{~h}$. Gross ash content was determined gravimetrically following loss of mass after combustion of a sample in a muffle furnace at $550^{\circ} \mathrm{C}$ for $12 \mathrm{~h}$. Protein was determined based on measurement of total nitrogen by CHNOS auto-analyser, and then multiplied by 6.25 . Total lipid content of the diets was determined gravimetrically following extraction of the lipids using chloroform:methanol (2:1). Gross energy was determined by ballistic bomb calorimetry. Total starch content was measured using enzymatic methods with the Megazyme Total Starch Kit, K-TSTA, following a modified AOAC Method 996.11. Total carbohydrates were calculated based on the dry matter content of a sample minus the protein, lipid and ash. Total non-starch polysaccharides were determined based on total carbohydrates minus total starch content. 
Amino acid analysis involved the samples being hydrolysed at $110^{\circ} \mathrm{C}$ for $24 \mathrm{~h}$ in $6 \mathrm{M} \mathrm{HCl}$ with 0.05 \% Phenol. Cystine was derivatized during hydrolysis by the addition of $0.05 \% 3-3-$ dithiodipropoinic acid. The acid hydrolysis destroyed tryptophan making it unable to be determined. Separation of the amino acids was performed by HPLC on a Hypersil AA-ODS $5 \mu m$ column using an 1100 series Hewlett Packard HPLC system. Fatty acids were analysed as methyl ester derivatives. Lipids were esterified by the method of O'Fallon et al. (2007) and analysed by gas chromatography (GC) using flame ionisation detection. Specific fatty acid peaks were identified by comparing retention times relative to standards. Total yttrium and phosphorus concentrations were determined using inductively coupled plasma mass spectrometry (ICP-MS) after mixed acid digestion based on the method described by McQuaker et al., (1979).

The apparent digestibility ( $\left.A D_{\text {diet }}\right)$ for each of the nutritional parameters examined in each diet was calculated based on the following formula (Maynard and Loosli, 1979):

$$
A D_{\text {diet }}=\left(1-\left(\frac{Y_{\text {diet }} \times \text { Parameter }_{\text {faeces }}}{Y_{\text {faeces }} \times \text { Parameter }_{\text {diet }}}\right)\right) \times 100
$$

where $Y_{\text {diet }}$ and $Y_{\text {faeces }}$ represent the yttrium content of the diet and faeces respectively, and

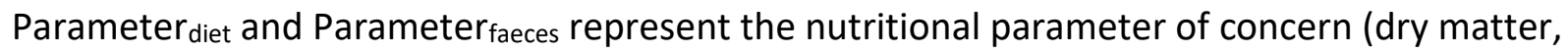
protein [and amino acids in one study] or energy) content of the diet and faeces respectively. The digestibility values for each of the test ingredients in the test diets examined in this study were calculated according to the formulae:

$$
\text { Nutr. } A D_{\text {ingredient }}=\frac{\left(A D_{\text {test }} \times N u t r_{\text {test }}-\left(A D_{\text {basal }} \times N u t r_{\text {basal }} \times 0.7\right)\right)}{\left(0.3 \times N u t r_{\text {ingredient }}\right)}
$$

Where Nutr.AD ingredient is the digestibility of a given nutrient from the test ingredient included in the test diet at $30 \%$. $A D_{\text {test }}$ is the apparent digestibility of the test diet. $A D_{\text {basal }}$ is the apparent digestibility of the basal diet, which makes up $70 \%$ of the test diet. Nutr Ingredient, Nutr $_{\text {test }}$ and Nutr $r_{\text {basal }}$ are the level of the nutrient of interest in the ingredient, test diet and basal diet respectively (as reviewed by Glencross et al., 2007).

\section{Statistical analysis}

All values are mean \pm SE unless otherwise specified. Effects of raw material type were not statistically evaluated as it was perceived that such a statistical comparison was irrelevant to the 
1 utility of this data in this study. Regression analysis was undertaken using the data analysis package of MSExcel. 
As expected there was a substantial range in the composition parameters observed for the different raw materials assessed (Table 3). Protein concentrations in the raw materials varied from $271 \mathrm{~g} \mathrm{~kg}^{-1} \mathrm{DM}$ in the Camelina meal to $965 \mathrm{~g} \mathrm{~kg}^{-1} \mathrm{DM}$ in the Soy protein isolate. Other than the different oil raw materials, the lipid concentrations were lowest in each of the Blood meals ( $1 \mathrm{~g}$ $\left.\mathrm{kg}^{-1} \mathrm{DM}\right)$ and highest in the Camelina meal (311 $\left.\mathrm{g} \mathrm{kg}^{-1} \mathrm{DM}\right)$. Energy densities were highest in the oil raw materials (fish oil, ricebran oil and poultry oil) at 38.4 to $39.7 \mathrm{MJ} \mathrm{kg}^{-1}$. The lowest energy densities were observed from one of the soy protein concentrates (17.5 MJ kg-1) though the Faba bean meal was also among the lower energy dense raw materials at $18.8 \mathrm{MJ} \mathrm{kg}^{-1}$. Amino acid

\section{Raw material digestibility}

There was a substantial range in the digestibilities of each of the parameters examined (dry matter, protein, lipid, energy, sum of amino acids and individual amino acids) across each of the three experiments presented. This largely reflected the different raw materials that were assessed, though there were some notable variations within specific raw material types. Raw material dry matter digestibilities ranged from $31 \%$ to $96 \%$ across the different raw materials, with an average of $59 \pm 2.4 \%$. Raw material protein digestibilities ranged from $36 \%$ to $106 \%$ across the twelve treatments, with an average of $81 \pm 2.6 \%$. Raw material lipid digestibilities ranged from $21 \%$ to $487 \%$ across the range of raw materials, with an average of $110 \pm 14.6 \%$. Raw material energy digestibilities ranged from $36 \%$ to $93 \%$, with an average of $67 \pm 2.3 \%$ (Table 4). Raw material sum of amino acid digestibilities ranged from $77 \%$ to $89 \%$ across the range of raw materials, with an average of $83 \pm 1.2 \%$ (Table 5). Among the individual amino acids the mean digestibilities ranged from $72 \%$ for threonine to $120 \%$ for proline. Some amino acids, like lysine, were consistently highly digestible across the different raw materials (Table 5).

Between certain digestibility parameters there were clear relationships. Raw material energy digestibility was clearly linked $(R=0.860, p=0.001)$ to protein digestibility (among those non-oil raw materials) (Table 4). However other expected relationships, like that between protein digestibility and of the sum of amino acids (SAA) digestibility (another way of examining protein digestibility) produced a poor regressions $(R=-0.244, p=0.675)$ (Table 5). 
This study examined the nutritional value of a series of alternative raw materials to the use of both fishmeal and fish oil in diets for juvenile barramundi. The focus of this assessment was the examination of the digestible nutrient and energy value of each of these raw materials so as to provide data suitable for the formulation of diets on a digestible nutrient and energy basis (Glencross et al., 2007). Additional to this a literature survey was conducted to compile this new data, with other digestibility data available for this species, into a single compendium (McMeniman, 1998; Glencross 2011; Glencross et al., 2011; 2012; 2014; Tabrett et al.. 2012; Blyth et al., 2014; Diu et al., 2015).

\section{Plant raw material digestibility}

A wide range of plant derived raw materials was evaluated in the present digestibility study. Among those examined was a series of soybean products, including solvent extracted soybean meals, soy protein concentrates (SPC) and soy protein isolate (SPI) and several other feed grain varieties. Soy products have generally been favourably used in diets for barramundi without many issues, despite a lack of digestibility data (Boonyaratpailin et al., 1998; Tantikitti et al., 2005). Of the different feed grain varieties studied in the present work the protein digestibility was generally high at around 90\%, though the dry matter and energy digestibilities were typically lower, reflecting the lower concentration of protein found in these raw materials (the exception being the highly processed products of SPC and SPI). Both McMeniman (1998) and Glencross (2011) previously examined the digestibility of solvent-extracted soybean meal in diets fed to barramundi and observed protein digestibilities of $85 \%$ and $103 \%$ respectively (Table 6 ). While it is often difficult to compare digestibility values across studies, without some form of reference, it can be seen that the range in protein digestibility values for such a common raw material can be quite expansive (65\% to $103 \%$ ) across all the combined studies. These differences could be due to a range of factors including the soybean genotype, growing environment, processing and not withstanding also the experimental methodologies used (Glencross et al., 2007).

However, substantial differences were also seen between the two SPC raw materials evaluated in the present studies and although there were subtle differences in the basal diets between the two experiments, otherwise experimental methodologies were kept uniform. Despite these consistencies in methodologies the protein digestibilities of the two SPC raw materials varied from $49 \%$ to $95 \%$ and the energy digestibilities observed for each raw material were consistent with there being such a substantial difference in protein digestibility between the two. 
Such differences may be explained by processing methods used to produce either product (Gatlin et al., 2007). Interesting was the observation of the protein digestibility of SPC-1 in terms of both nitrogen and sum of amino acids, both used as proxies for determining protein digestibility, in that they were quite divergent. This observation perhaps suggests that there might have been a significant level of non-protein nitrogen associated with SPC-1 that was not absorbed by the animal. This observation also raises the question as to the more appropriate way to assess protein digestibility, from nitrogen or sum of amino acid data. While in other studies there has been a good regression between these two parameters in the present study this divergence casts some doubt on the validity of either method (Glencross et al., 2008). Logic suggests that the use of sum of amino acids provides a more valid assessment as it is less likely that there are non-protein amino acids in the raw materials than non-protein nitrogen sources (Krober \& Gibbons, 1962). However, sum of amino acids does not account for tryptophan, albeit levels of this amino acid in most raw materials are very low and the comparison is still consistent across all samples.

There were also no other published reports on the digestible value of SPCs when fed to barramundi, but other data on protein concentrates from lupins were found (Glencross, 2011). Each of the lupin protein concentrates studied also had high protein and energy digestibilities. However, protein concentrates from other grain species such as canola/rapeseed, field peas or faba beans remain to be explored. Certainly studies on understanding the influence of different carbohydrate classes and non-starch polysaccharides on the digestibility of diets by this species provides a clear mechanism for understanding why some substantial differences are observed among some of the plant protein raw materials (Irvin et al., 2015).

Among the other plant protein raw materials examined in the present study a consistently high level of protein digestibility ( $90 \%$ to $95 \%)$ was observed. The exception to this was the Camelina meal which produced both protein and energy digestibility values of $36 \%$. There was no other data in the literature on digestibility values of Camelina meal when fed to barramundi in which to compare, however some data was found on growth responses from work with Atlantic salmon (Hixson et al., 2014). That work found little impact from the inclusion of $100 \mathrm{~g} \mathrm{~kg}^{-1}$ of camelina meal, although the diet did contain high fishmeal levels $\left(\sim 318 \mathrm{~g} \mathrm{~kg}^{-1}\right)$. There were however several studies on the digestibility of lupin and canola meals (Glencross, 2011; Tabrett et al., 2012; Diu et al., 2015). The literature values found for lupin kernel meal protein digestibilities varied among the different lupins species evaluated, but ranged from $81 \%$ to $109 \%$. For the Lupinus angustifolius species evaluated in the present study this range was substantially smaller (86\% to $98 \%$ ). Notably in some studies where the same sample of lupin kernel meal was used 
across studies a highly conserved range of protein digestibility values were observed. Values of 96\% to $97 \%$ were seen for the L. angustifolius cv. Myallie variety (Glencross, 2011; Tabrett et al., 2012) and $86 \%$ to $90 \%$ were seen for the L. angustifolius cv. Coromup variety (Diu et al., 2015; present study). This observation suggests that the between study variation is perhaps smaller than the between variety variation.

\section{Animal raw material digestibility}

A range of animal derived raw materials were also evaluated in the present digestibility study. Among those examined was a series of blood meal products and poultry offal meals. Each of the three blood meals examined had protein digestibilities that were observed to be similar to or better than that of the poultry offal meal or fish (tuna by-product) meal. Notably two of the blood meals had protein digestibilities above $100 \%$, with one clearly lower at $83 \%$. Reasons for why this difference existed among the blood meals are not clear as no information was provided from the supplier on the basis of the sample origin variability, other than it is suspected they were from different rendering plants. Clearly to follow this up further a more direct approach to rendering plants needs to be undertaken rather than obtaining samples from a feed producer. Other studies examining rendered mammalian meals with both barramundi and other species have also identified substantial variability in digestible values for these raw materials (McMeniman, 1998; Bureau et al., 1999).

Amino acid digestibilities of the poultry offal meal and tuna offal meal were quite similar, except for one or two amino acids. Those amino acids that were quite different between these two raw materials included cysteine and serine. Overall the sum of amino acid digestibilities were also quite different at $77 \%$ and $87 \%$ and these contrasted those of the nitrogen digestibilities $87 \%$ and $71 \%$ respectively for the same two samples. As with the plant protein raw materials there is a range of reasons why this difference may exist, however this cannot be reasonably explored based on the assessment of two raw material samples and clearly further work on this issue is warranted.

\section{Lipid raw material digestibility}

Each of the three lipid raw materials examined in the present study had lipid and/or energy digestibilities that were observed to be similar amongst each other with no clear better or inferior product. Although there have been a few studies examining lipid raw materials in barramundi, no data was found determining the digestibility of any lipid resources in this species (Alhazzaa et al., 
1 2011; Salini et al., 2015). It would be useful to not only follow this work up with assessment of

2 additional lipid raw materials, but also to assess the discrete digestibilities of individual fatty acids

3 from within the different lipid raw materials.

\section{Conclusions}

The findings from this compendium provide a useful resource to enable nutritionists to

7 formulate diets for barramundi on a digestible nutrient and energy basis. To further reduce feed

8 risk, additional raw materials need evaluation and dissemination of this data remains one of the

9 highest priorities to provide enhanced flexibility for formulation options for use in barramundi

10 feeds (Glencross et al., 2007). In addition to assessing the digestibility of additional raw materials,

11 it was clear from this study that there is considerable variability in the nutritional value of raw

12 materials, not only between types, but even within types. Therefore, to follow from this work

13 further effort needs to be spent on defining those factors that affect the nutritional value within

14 classes of raw materials. This can most notably be achieved by defining their digestible value

15 relative to their chemical composition (Glencross, 2011; Glencross et al., 2007; 2011).

\section{Acknowledgments}

Thanks also to Nick Polymeris, Natalie Habilay, Kiname Salee and Dylan Rylatt for technical assistance. 


\section{References}

Alhazzaa, R., Bridle, A.R., Nichols, P.D. \& Carter, C.G., (2011) Replacing dietary fish oil with Echium oil enriched barramundi with C18 PUFA rather than long-chain PUFA. Aquaculture 312, $162-171$

Aslaksen, M.A., Kraugerud, O.F., Penn, M., Svihus, B., Denstadli, V., Jorgensen, H.Y., Hillestad, M., Krogdahl, A. \& Storebakken, T., (2007) Screening of nutrient digestibilities and intestinal pathologies in Atlantic salmon, Salmo salar, fed diets with legumes, oilseeds, or cereals. Aquaculture 272, 541-555.

Blyth, D., Tabrett, S.J. \& Glencross, B.D., (2015) A study of the effects of faecal collection method and acclimation time on the digestibility of diets and ingredients when fed to juvenile barramundi (Lates calcarifer). Aquaculture Nutrition 21, 248-255. DOI: 10.1111/anu.12159.

Boonyaratpalin, M., Suraneiranat, P. \& Tunpibal, T., (1998) Replacement of fish meal with various types of soybean products in diets for the Asian sea bass, Lates calcarifer. Aquaculture $161,67-78$

Bureau, D.P., Harris, A.M. \& Cho, C.Y., (1999) Apparent digestibility of rendered animal protein ingredients for rainbow trout (Oncorhynchus mykiss). Aquaculture 180, 345-358.

Diu, N.T., Pirozzi, I. \& Glencross, B.D., (2015). Digestibility of canola meals in barramundi (Asian seabass; Lates calcarifer). Aquaculture 435, 442-449.

Gatlin, D.M., Barrows, F.T., Brown, P., Dabrowski, K., Gaylord, T.G., Hardy, R.W., Herman, E., Hu, G., Krogdahl, A., Nelson, R., Overturf, K., Rust, M., Sealy, W., Skonberg, D., Souza, E.J., Stone, D., Wilson, R. \& Wurtele, E. (2007) Expanding the utilisation of sustainable plant products in aquafeeds: a review. Aquaculture Research 38, 551-579.

Glencross, B.D., (2006) Nutritional management of barramundi, Lates calcarifer - A review. Aquaculture Nutrition 12, 291-309.

Glencross, B.D., (2009) Exploring the nutritional demand for essential fatty acids by aquaculture species. Reviews in Aquaculture 1, 71-124

Glencross, B.D., (2011) A comparison of the diet and raw material digestibilities between rainbow trout (Oncorhynchus mykiss) and barramundi (Lates calcarifer) - Implications for inferences of digestibility among species. Aquaculture Nutrition 17, e207-e215.

Glencross, B.D., Booth, M. \& Allan, G.L., (2007) A feed is only as good as its ingredients - A review of ingredient evaluation for aquaculture feeds. Aquaculture Nutrition 13, $17-34$. 
Glencross, B.D., Hawkins, W.E., Evans, D., Rutherford, N., McCafferty, P., Dods, K. \& Sipsas, S., (2008) Assessing the implications of variability in the digestible protein and energy value of lupin kernel meals when fed to rainbow trout, Oncorhynchus mykiss. Aquaculture 277, 251-262.

Glencross, B.D., Rutherford, N.R. \& Jones, J.B., (2011) Fishmeal replacement options for juvenile barramundi (Lates calcarifer). Aquaculture Nutrition 17; e722-e732.

Glencross, B.D., Blyth D., Tabrett, S.J., Bourne, N., Irvin, S., Fox-Smith, T. \& Smullen, R.P., (2012). An examination of digestibility and technical qualities of a range of cereal grains when fed to juvenile barramundi (Lates calcarifer) in extruded diets. Aquaculture Nutrition 18, 388399.

Glencross, B., Wade, N. \& Morton, K., (2013) Chapter 8. Lates calcarifer nutrition and feeding practices. In: Barramundi. (D.R. Jerry, F. Ayson. Eds.) CAB International, Wallingford UK. pp 178-228.

Glencross, B.D., Blyth, D., Bourne, N., Irvin, S. \& Wade, N.P., (2014) An analysis of the effects of different dietary macronutrient energy sources on the growth and energy partitioning by juvenile barramundi, Lates calcarifer, reveal a preference for protein-derived energy. Aquaculture Nutrition 20, 583-594.

Glencross, B.D., Irvin, S., Blyth, D., Bourne, N., Campet, M., Boisot, P. \& Wade, N., (2016) An evaluation of the complete replacement of both fishmeal and fish oil in diets for juvenile Asian seabass, Lates calcarifer. Aquaculture 451, 298-309.

Hixson, S.M., Parrish, C.C. \& Anderson, D.M., (2014) Full substitution of fish oil with camelina (Camelina sativa) oil, with partial substitution of fish meal with camelina meal, in diets for farmed Atlantic salmon (Salmo salar) and its effect on tissue lipids an sensory quality. Food Chemistry 157, 51-61.

Irvin, S., Blyth, D., Bourne, N. \& Glencross, B.D., (2015) Examining the discrete and interactive effect of different NSP non-starch polysaccharide (NSP) sources on feed digestibility by barramundi, Lates calcarifer. Aquaculture Nutrition DOI: 10.1111/anu.12321.

Krober, O.A. \& Gibbons, S.J., (1962) Composition of Feedstuffs, Nonprotein Nitrogen in Soybeans. J. Agric. Food Chem. 10, 57-59.

Maynard, L.A. \& Loosli, J.K. (1979) Animal Nutrition, 6th Edition. New York, NY: McGraw-Hill Book Co.

McMeniman, N., (1998) The apparent digestibility of feed ingredients based on stripping methods. In: Fishmeal Replacement in Aquaculture Feeds for Barramundi (K.C. Williams Ed.). 
Project 93/120-04. Final Report to Fisheries R\&D Corporation. Canberra, Australia. pp 4670.

McQuaker, N.R., Brown, D.F. \& Kluckner, P.D., (1979) Digestion of environmental materials for analysis by Inductively Coupled Plasma - Atomic Emission Spectrometry. Analytical Chemistry 51, 1082-1084.

O'Fallon, J.V., Busboom, J.R., Nelson, M.L. \& Gaskins, C.T., (2007) A direct method for fatty acid methyl ester (FAME) synthesis: Application to wet meat, tissues, oils \& feedstuffs. Journal of Animal Science 85,1511-1522.

Salini, M., Irvin, S., Bourne, N., Blyth, D., Cheers, S., Habilay, N. \& Glencross, B.D., (2015) Marginal efficiencies of long chain-polyunsaturated fatty acid use by barramundi (Lates calcarifer) when fed diets with varying blends of fish oil and poultry fat. Aquaculture 449, 48-57. doi.org/10.1016/j.aquaculture

Tabrett, S.J., Blyth D. \& Glencross, B.D., (2012) An examination of the variability in the digestibility of kernel meals of different cultivars of the white lupin, Lupinus albus fed to juvenile barramundi (Lates calcarifer). Aquaculture 364-365. 1-5.

Tacon, A.G.J. \& Metian, M., (2008) Global overview on the use of fish meal and fish oil in industrially compounded aquafeeds: Trends and future prospects. Aquaculture $285,146-$ 158

Tantikitti, C., Sangpong, W. \& Chiavareesajja, S., (2005) Effects of defatted soybean protein levels on growth performance and nitrogen and phosphorus excretion in Asian seabass (Lates calcarifer). Aquaculture 248, 41-50.

Williams, K.C., Barlow, C.G. \& Rodgers, L., (2001) Efficacy of crystalline and protein-bound amino acids for amino acid enrichment of diets for barramundi/Asian seabass (Lates calcarifer Bloch). Aquaculture Research 32, 415-429.

Williams, K.C., Barlow, C.G., Rodgers, L., Hockings, I., Agcopra, C. \& Ruscoe, I., (2003a) Asian seabass Lates calcarifer perform well when fed pellet diets high in protein and lipid. Aquaculture 225, 191-206.

Williams, K.C., Barlow, C.G., Rodgers, L. \& Ruscoe, I., (2003b) Potential of meat meal to replace fish meal in extruded dry diets for barramundi Lates calcarifer (Bloch). I. Growth performance. Aquaculture Research 34, 23-32. 
Table 1. Formulations and composition of each of the basal diets used in each experiment (all values are $\mathrm{g} \mathrm{kg}^{-1}$ as used unless otherwise indicated).

\begin{tabular}{|c|c|c|c|}
\hline Experiment & BAR-10-1 & BAR-12-2 & BAR-14-1 \\
\hline \multicolumn{4}{|l|}{ Raw material } \\
\hline Fishmeal (Anchovetta) & 640 & 764 & 750 \\
\hline Fish oil & 100 & 50 & 20 \\
\hline Wheat flour & - & 80 & 224 \\
\hline Wheat gluten & 130 & - & - \\
\hline Cellulose & 124 & 100 & - \\
\hline Vitamin and mineral premix* & 5 & 5 & 5 \\
\hline Yttrium oxide & 1 & 1 & 1 \\
\hline \multicolumn{4}{|l|}{ Diet composition } \\
\hline Dry matter ( $\left.\mathrm{g} \mathrm{kg}^{-1}\right)$ & 959 & 972 & 973 \\
\hline Protein & 546 & 546 & 598 \\
\hline Lipid & 129 & 136 & 97 \\
\hline Ash & 106 & 143 & 160 \\
\hline Energy (MJ kg-1 DM) & 22.1 & 20.7 & 21.5 \\
\hline sum Amino Acids & 509 & 502 & 524 \\
\hline Alanine & 38 & 34 & 32 \\
\hline Arginine & 28 & 30 & 27 \\
\hline Asparagine & 31 & 49 & 30 \\
\hline Cysteine & 6 & 6 & 6 \\
\hline Glutamate & 54 & 69 & 47 \\
\hline Glycine & 36 & 34 & 23 \\
\hline Histidine & 16 & 17 & 16 \\
\hline Isoleucine & 39 & 23 & 41 \\
\hline Leucine & 84 & 40 & 98 \\
\hline Lysine & 39 & 42 & 38 \\
\hline Methionine & 13 & 18 & 40 \\
\hline Phenylalanine & 31 & 21 & 29 \\
\hline Proline & 26 & 25 & 20 \\
\hline Serine & 20 & 24 & 18 \\
\hline Taurine & 4 & 5 & 3 \\
\hline Threonine & 20 & 24 & 20 \\
\hline Tyrosine & 20 & 17 & 16 \\
\hline Valine & 20 & 25 & 20 \\
\hline
\end{tabular}

* Vitamin and mineral premix includes (IU/kg or g/kg of premix): Vitamin A, 2.5MIU; Vitamin D3, $0.25 \mathrm{MIU}$; Vitamin E, 16.7 g; Vitamin K,3, 1.7 g; Vitamin B1, 2.5 g; Vitamin B2, 4.2 g; Vitamin B3, 25 g; Vitamin B5, 8.3; Vitamin B6, 2.0 g; Vitamin B9, 0.8; Vitamin B12, 0.005 g; Biotin, 0.17 g; Vitamin C, 75 g; Choline, 166.7 g; Inositol, $58.3 \mathrm{~g}$; Ethoxyquin, $20.8 \mathrm{~g}$; Copper, $2.5 \mathrm{~g}$; Ferrous iron, $10.0 \mathrm{~g}$; Magnesium, $16.6 \mathrm{~g}$; Manganese, 15.0 g; Zinc, $25.0 \mathrm{~g}$. 
Table 2. Operational parameters of each experiment.

\begin{tabular}{ccccc}
\hline Experiment & $\begin{array}{c}\text { Temperature } \\
\text { oC }\end{array}$ & $\begin{array}{c}\text { DO } \\
\mathrm{mg} \mathrm{L}^{-1}\end{array}$ & $\begin{array}{c}\text { Tank Volume } \\
\mathrm{L}\end{array}$ & $\begin{array}{c}\text { Fish Weight } \\
\mathrm{g} \mathrm{fish}^{-1}\end{array}$ \\
\hline & & & & \\
BAR-10-1 & $28.8 \pm 0.22$ & $6.4 \pm 0.15$ & 250 & $398 \pm 68.8$ \\
BAR-12-2 & $29.9 \pm 0.12$ & $5.5 \pm 0.56$ & 250 & $179 \pm 73.0$ \\
BAR-14-1 & $30.3 \pm 1.50$ & $6.2 \pm 0.1$ & 1000 & $439 \pm 97.2$ \\
& & & & \\
\hline
\end{tabular}


Table 3. Composition of test ingredients

\begin{tabular}{|c|c|c|c|c|c|c|c|c|c|c|c|c|c|c|c|c|}
\hline & $\begin{array}{l}\text { Tuna } \\
\text { Offal } \\
\text { Meal }\end{array}$ & $\begin{array}{c}\text { Poultry } \\
\text { Offal } \\
\text { Meal }\end{array}$ & $\begin{array}{c}\text { Blood } \\
\text { Meal } \\
1\end{array}$ & $\begin{array}{c}\text { Blood } \\
\text { Meal } \\
2\end{array}$ & $\begin{array}{c}\text { Blood } \\
\text { Meal } \\
3\end{array}$ & $\begin{array}{c}\text { Soybean } \\
\text { Meal } \\
1\end{array}$ & $\begin{array}{c}\text { Soybean } \\
\text { Meal } \\
2\end{array}$ & $\begin{array}{l}\text { Camelina } \\
\text { Meal }\end{array}$ & $\begin{array}{l}\text { Lupin } \\
\text { Kernel } \\
\text { Meal }\end{array}$ & $\begin{array}{l}\text { Faba } \\
\text { Bean } \\
\text { Meal }\end{array}$ & $\begin{array}{c}\text { SPC } 1 \\
\text { (Wilmar) }\end{array}$ & $\begin{array}{c}\text { SPC 2 } \\
\text { (Selecta) }\end{array}$ & $\begin{array}{c}\text { SPI } \\
\text { (ADM) }\end{array}$ & $\begin{array}{l}\text { Fish } \\
\text { oil }\end{array}$ & $\begin{array}{c}\text { Ricebran } \\
\text { Oil }\end{array}$ & $\begin{array}{c}\text { Poultry } \\
\text { Oil }\end{array}$ \\
\hline Experiment & B-12-2 & B-12-2 & B-10-1 & B-10-1 & B-10-1 & B-12-2 & B-14-1 & B-14-1 & B-14-1 & B-14-1 & B-12-2 & B-14-1 & B-12-2 & B-12-2 & B-12-2 & B-12-2 \\
\hline Dry matter $\left(\mathrm{g} \mathrm{kg}^{-1}\right)$ & 920 & 974 & 935 & 937 & 872 & 877 & 897 & 933 & 916 & 905 & 871 & 923 & 896 & 1000 & 997 & 990 \\
\hline Protein $(\mathrm{N} \times 6.25)$ & 657 & 530 & 936 & 887 & 953 & 515 & 456 & 271 & 465 & 309 & 723 & 657 & 965 & 4 & 6 & 13 \\
\hline Lipid & 85 & 179 & 1 & 1 & 1 & 27 & 94 & 311 & 87 & 22 & 14 & 29 & 57 & 993 & 912 & 939 \\
\hline $\mathrm{CHO}$ & 7 & 138 & 46 & 94 & 26 & 386 & 390 & 372 & 417 & 641 & 197 & 237 & 0 & 3 & 80 & 59 \\
\hline Ash & 243 & 149 & 17 & 18 & 20 & 68 & 60 & 46 & 31 & 28 & 66 & 77 & 33 & 0 & 0 & 0 \\
\hline Energy $\left(\mathrm{MJ} \mathrm{kg}^{-1}\right)$ & 19.4 & 22.6 & 24.5 & 24.6 & 25.1 & 20.1 & 21.9 & 26.3 & 21.3 & 18.8 & 17.5 & 21.4 & 20.6 & 38.6 & 39.7 & 38.4 \\
\hline$\sum$ Amino Acids & 590 & 619 & 989 & 983 & 939 & 478 & 413 & 246 & 390 & 248 & 644 & 590 & 855 & - & - & - \\
\hline Alanine & 41 & 41 & 77 & 77 & 74 & 22 & 22 & 12 & 17 & 12 & 28 & 24 & 35 & - & - & - \\
\hline Arginine & 38 & 45 & 43 & 43 & 51 & 36 & 29 & 20 & 44 & 24 & 50 & 45 & 68 & - & - & - \\
\hline Aspartic acid & 59 & 52 & 101 & 100 & 89 & 57 & 34 & 15 & 31 & 23 & 77 & 45 & 103 & - & - & - \\
\hline Cysteine & 9 & 13 & 16 & 16 & 18 & 9 & 7 & 6 & 5 & 3 & 10 & 9 & 13 & - & - & - \\
\hline Glutamic acid & 78 & 83 & 91 & 90 & 99 & 89 & 34 & 26 & 34 & 20 & 123 & 47 & 172 & - & - & - \\
\hline Glycine & 44 & 58 & 40 & 40 & 37 & 20 & 29 & 17 & 35 & 18 & 27 & 39 & 35 & - & - & - \\
\hline Histidine & 17 & 12 & 58 & 57 & 48 & 14 & 12 & 7 & 12 & 6 & 17 & 20 & 22 & - & - & - \\
\hline Isoleucine & 26 & 26 & 16 & 16 & 36 & 21 & 34 & 18 & 31 & 19 & 28 & 45 & 38 & - & - & - \\
\hline Leucine & 48 & 48 & 119 & 118 & 102 & 38 & 60 & 30 & 50 & 45 & 52 & 67 & 68 & - & - & - \\
\hline Lysine & 47 & 33 & 88 & 87 & 81 & 26 & 32 & 18 & 29 & 19 & 37 & 42 & 46 & - & - & - \\
\hline Methionine & 19 & 15 & 16 & 17 & 15 & 8 & 8 & 11 & 4 & 6 & 9 & 25 & 12 & - & - & - \\
\hline Phenylalanine & 26 & 28 & 70 & 70 & 60 & 26 & 34 & 15 & 23 & 15 & 35 & 58 & 47 & - & - & - \\
\hline Proline & 29 & 46 & 44 & 44 & 43 & 24 & 20 & 13 & 16 & 11 & 31 & 29 & 43 & - & - & - \\
\hline Serine & 28 & 39 & 50 & 50 & 44 & 28 & 20 & 11 & 18 & 11 & 38 & 28 & 50 & - & - & - \\
\hline Taurine & 1 & 2 & 0 & 0 & 0 & 0 & 0 & 0 & 0 & 0 & 0 & 0 & 1 & - & - & - \\
\hline Threonine & 30 & 27 & 53 & 51 & 50 & 21 & 16 & 10 & 14 & 8 & 28 & 24 & 34 & - & - & - \\
\hline Tyrosine & 20 & 20 & 31 & 32 & 33 & 18 & 7 & 6 & 12 & 0 & 24 & 22 & 30 & - & - & - \\
\hline Valine & 30 & 31 & 76 & 75 & 59 & 21 & 15 & 11 & 13 & 9 & 30 & 22 & 38 & - & - & - \\
\hline C14:0 & 3.0 & 1.2 & $\mathrm{n} / \mathrm{a}$ & $\mathrm{n} / \mathrm{a}$ & $\mathrm{n} / \mathrm{a}$ & 0.0 & $\mathrm{n} / \mathrm{a}$ & $\mathrm{n} / \mathrm{a}$ & $\mathrm{n} / \mathrm{a}$ & $\mathrm{n} / \mathrm{a}$ & 0.6 & $\mathrm{n} / \mathrm{a}$ & 0.0 & 8.2 & 0.5 & 1.1 \\
\hline
\end{tabular}




\begin{tabular}{|c|c|c|c|c|c|c|c|c|c|c|c|c|c|c|c|c|}
\hline C16:0 & 25.3 & 24.6 & $\mathrm{n} / \mathrm{a}$ & $\mathrm{n} / \mathrm{a}$ & $\mathrm{n} / \mathrm{a}$ & 17.4 & $\mathrm{n} / \mathrm{a}$ & $\mathrm{n} / \mathrm{a}$ & $\mathrm{n} / \mathrm{a}$ & $\mathrm{n} / \mathrm{a}$ & 17.3 & $\mathrm{n} / \mathrm{a}$ & 14.9 & 18.9 & 19.8 & 0.0 \\
\hline C18:0 & 9.6 & 9.1 & $n / a$ & $\mathrm{n} / \mathrm{a}$ & $\mathrm{n} / \mathrm{a}$ & 4.9 & $\mathrm{n} / \mathrm{a}$ & $\mathrm{n} / \mathrm{a}$ & $\mathrm{n} / \mathrm{a}$ & $\mathrm{n} / \mathrm{a}$ & 4.7 & $\mathrm{n} / \mathrm{a}$ & 5.2 & 3.7 & 2.2 & 0.0 \\
\hline C16:1 & 3.6 & 6.9 & $n / a$ & $\mathrm{n} / \mathrm{a}$ & $\mathrm{n} / \mathrm{a}$ & 0.0 & $n / a$ & $\mathrm{n} / \mathrm{a}$ & $\mathrm{n} / \mathrm{a}$ & $\mathrm{n} / \mathrm{a}$ & 0.8 & $\mathrm{n} / \mathrm{a}$ & 0.0 & 10.2 & 0.0 & 6.9 \\
\hline C18:1 & 17.7 & 43.4 & $n / a$ & $\mathrm{n} / \mathrm{a}$ & $\mathrm{n} / \mathrm{a}$ & 15.6 & $\mathrm{n} / \mathrm{a}$ & $\mathrm{n} / \mathrm{a}$ & $\mathrm{n} / \mathrm{a}$ & $\mathrm{n} / \mathrm{a}$ & 26.3 & $\mathrm{n} / \mathrm{a}$ & 23.2 & 13.6 & 41.8 & 66.1 \\
\hline$C 18: 2 n-6$ & 2.8 & 11.3 & $n / a$ & $\mathrm{n} / \mathrm{a}$ & $\mathrm{n} / \mathrm{a}$ & 53.4 & $\mathrm{n} / \mathrm{a}$ & $\mathrm{n} / \mathrm{a}$ & $\mathrm{n} / \mathrm{a}$ & $\mathrm{n} / \mathrm{a}$ & 41.7 & $\mathrm{n} / \mathrm{a}$ & 49.8 & 1.9 & 32.4 & 20.6 \\
\hline C18:3n-3 & 0.0 & 1.5 & $\mathrm{n} / \mathrm{a}$ & $\mathrm{n} / \mathrm{a}$ & $\mathrm{n} / \mathrm{a}$ & 8.2 & $\mathrm{n} / \mathrm{a}$ & $\mathrm{n} / \mathrm{a}$ & $\mathrm{n} / \mathrm{a}$ & $\mathrm{n} / \mathrm{a}$ & 4.6 & $\mathrm{n} / \mathrm{a}$ & 6.9 & 0.7 & 1.2 & 2.5 \\
\hline$C 20: 4 n-6$ & 2.6 & 1.3 & $n / a$ & $\mathrm{n} / \mathrm{a}$ & $n / a$ & 0.0 & $\mathrm{n} / \mathrm{a}$ & $\mathrm{n} / \mathrm{a}$ & $\mathrm{n} / \mathrm{a}$ & $\mathrm{n} / \mathrm{a}$ & 0.0 & $\mathrm{n} / \mathrm{a}$ & 0.0 & 1.1 & 0.0 & 0.0 \\
\hline$C 20: 5 n-3$ & 4.6 & 0.0 & $\mathrm{n} / \mathrm{a}$ & $\mathrm{n} / \mathrm{a}$ & $\mathrm{n} / \mathrm{a}$ & 0.0 & $\mathrm{n} / \mathrm{a}$ & $\mathrm{n} / \mathrm{a}$ & $\mathrm{n} / \mathrm{a}$ & $\mathrm{n} / \mathrm{a}$ & 0.4 & $\mathrm{n} / \mathrm{a}$ & 0.0 & 17.6 & 0.0 & 0.0 \\
\hline$C 22: 6 n-3$ & 23.5 & 0.8 & $n / a$ & $\mathrm{n} / \mathrm{a}$ & $\mathrm{n} / \mathrm{a}$ & 0.0 & $\mathrm{n} / \mathrm{a}$ & $\mathrm{n} / \mathrm{a}$ & $\mathrm{n} / \mathrm{a}$ & $\mathrm{n} / \mathrm{a}$ & 0.0 & $\mathrm{n} / \mathrm{a}$ & 0.0 & 13.9 & 0.0 & 0.0 \\
\hline$\sum \mathrm{SFA}$ & 40.8 & 34.9 & $n / a$ & $\mathrm{n} / \mathrm{a}$ & $n / a$ & 22.8 & $\mathrm{n} / \mathrm{a}$ & $\mathrm{n} / \mathrm{a}$ & $\mathrm{n} / \mathrm{a}$ & $\mathrm{n} / \mathrm{a}$ & 24.6 & $\mathrm{n} / \mathrm{a}$ & 20.1 & 33.1 & 23.7 & 2.1 \\
\hline$\sum M U F A$ & 24.4 & 50.2 & $n / a$ & $\mathrm{n} / \mathrm{a}$ & $\mathrm{n} / \mathrm{a}$ & 15.6 & $\mathrm{n} / \mathrm{a}$ & $\mathrm{n} / \mathrm{a}$ & $\mathrm{n} / \mathrm{a}$ & $\mathrm{n} / \mathrm{a}$ & 28.7 & $\mathrm{n} / \mathrm{a}$ & 23.2 & 26.2 & 42.3 & 73.9 \\
\hline$\sum$ PUFA & 2.8 & 12.8 & $n / a$ & $\mathrm{n} / \mathrm{a}$ & $n / a$ & 61.6 & $\mathrm{n} / \mathrm{a}$ & $\mathrm{n} / \mathrm{a}$ & $\mathrm{n} / \mathrm{a}$ & $\mathrm{n} / \mathrm{a}$ & 46.2 & $\mathrm{n} / \mathrm{a}$ & 56.6 & 5.9 & 33.6 & 23.5 \\
\hline$\sum$ LC-PUFA & 32.0 & 2.1 & $\mathrm{n} / \mathrm{a}$ & $n / a$ & $n / a$ & 0.0 & $\mathrm{n} / \mathrm{a}$ & $n / a$ & $\mathrm{n} / \mathrm{a}$ & $\mathrm{n} / \mathrm{a}$ & 0.4 & $n / a$ & 0.0 & 34.9 & 0.5 & 0.4 \\
\hline$\sum n-3$ & 29.3 & 2.3 & $\mathrm{n} / \mathrm{a}$ & $\mathrm{n} / \mathrm{a}$ & $\mathrm{n} / \mathrm{a}$ & 8.2 & $\mathrm{n} / \mathrm{a}$ & $\mathrm{n} / \mathrm{a}$ & $\mathrm{n} / \mathrm{a}$ & $\mathrm{n} / \mathrm{a}$ & 5.0 & $\mathrm{n} / \mathrm{a}$ & 6.9 & 37.4 & 1.6 & 3.2 \\
\hline$\sum n-6$ & 5.5 & 12.6 & $n / a$ & $\mathrm{n} / \mathrm{a}$ & $\mathrm{n} / \mathrm{a}$ & 53.4 & $\mathrm{n} / \mathrm{a}$ & $\mathrm{n} / \mathrm{a}$ & $\mathrm{n} / \mathrm{a}$ & $\mathrm{n} / \mathrm{a}$ & 41.7 & $\mathrm{n} / \mathrm{a}$ & 49.8 & 3.0 & 32.4 & 20.8 \\
\hline
\end{tabular}

Unless otherwise indicated all data is g/kg DM except fatty acid data which is \% of total fatty acids. n/a: not analysed. ADM, Decatur, IL, USA.; Alfaone, Condell Park, NSW, Australia; Aus-Oils,

Kojonup, WA, Australia; BEC Feed Solutions, Carole Park, QLD, Australia; CSIRO Plant Industries, Black Mountain, ACT, Australia; COGGO, Winthrop, WA, Australia; Coorow Seed Cleaners,

Coorow, WA, Australia; Manildra, Auburn, NSW, Australia; Ridley Aquafeeds, Narangba, QLD, Australia; Selecta, Araguari, Brazil; Skretting Australia, Cambridge, TAS, Australia ; Wilmar,

Singapore. 
Table 4.

Raw material digestibilities (\%)

\begin{tabular}{|c|c|c|c|c|c|c|}
\hline Experiment & Ingredient & Origin & Dry matter & Protein & Lipid & Energy \\
\hline BAR-10-1 & Blood Meal 1 & Skretting Australia & 96 & 83 & - & 73 \\
\hline BAR-10-1 & Blood Meal 2 & Skretting Australia & 84 & 102 & - & 80 \\
\hline BAR-10-1 & Blood Meal 3 & Skretting Australia & 83 & 106 & - & 76 \\
\hline BAR-12-2 & Soy Protein Concentrate & Wilmar & 53 & 49 & 85 & 49 \\
\hline BAR-12-2 & Soybean Meal (Solvent-Extracted) & BEC Feed Solutions & 31 & 68 & 57 & 35 \\
\hline BAR-12-2 & Soy Protein Isolate & ADM & 53 & 74 & 21 & 56 \\
\hline BAR-12-2 & Poultry Offal Meal & BEC Feed Solutions & 42 & 87 & 89 & 65 \\
\hline BAR-12-2 & Fishmeal (Tuna Offal Meal) & BEC Feed Solutions & 49 & 71 & 45 & 56 \\
\hline BAR-12-2 & Ricebran oil & Alfaone & - & - & 82 & 93 \\
\hline BAR-12-2 & Fish oil (Peruvian anchovetta) & Ridley Aquafeeds & - & - & 84 & 92 \\
\hline BAR-12-2 & Poultry oil & Ridley Aquafeeds & - & - & 80 & 83 \\
\hline BAR-14-1 & Soy Protein Concentrate & Selecta & 65 & 95 & 136 & 77 \\
\hline BAR-14-1 & Camelina Meal & Aus-Oils & 41 & 36 & 64 & 36 \\
\hline BAR-14-1 & Lupin (L. angustifolius cv. Coromup) Kernel Meal & Coorow Seed Cleaners & 67 & 90 & 100 & 61 \\
\hline BAR-14-1 & Soybean Meal (Solvent-Extracted) & Ridley Aquafeeds & 60 & 92 & 103 & 63 \\
\hline BAR-14-1 & Faba Bean Meal & Ridley Aquafeeds & 42 & 95 & 487 & 67 \\
\hline
\end{tabular}


Table 5. Raw material amino acid digestibilities (\%) derived from Experiment BAR-12-2.

\begin{tabular}{|c|c|c|c|c|c|c|}
\hline Ingredient & SPC-1 & SBM-1 & SPI & POM & $\mathrm{FISH}$ & $\begin{array}{c}\text { Pooled } \\
\text { SEM }\end{array}$ \\
\hline Protein* & 49 & 68 & 74 & 87 & 71 & 2.8 \\
\hline sum Amino Acids & 81 & 89 & 83 & 77 & 87 & 1.2 \\
\hline Alanine & 89 & 93 & 78 & 83 & 88 & 2.1 \\
\hline Arginine & 86 & 126 & 81 & 81 & 87 & 2.1 \\
\hline Asparagine & 68 & 85 & 85 & 71 & 82 & 1.6 \\
\hline Cysteine & 65 & 53 & 67 & 69 & 92 & 2.3 \\
\hline Glutamate & 79 & 90 & 87 & 76 & 80 & 1.2 \\
\hline Glycine & 82 & 79 & 97 & 87 & 91 & 2.8 \\
\hline Histidine & 68 & 50 & 62 & 94 & 91 & 2.5 \\
\hline Isoleucine & 105 & 140 & 86 & 90 & 104 & 2.6 \\
\hline Leucine & 89 & 104 & 82 & 79 & 87 & 1.4 \\
\hline Lysine & 97 & 97 & 101 & 115 & 109 & 3.0 \\
\hline Methionine & 102 & 82 & 80 & 92 & 95 & 3.5 \\
\hline Phenylalanine & 85 & 97 & 78 & 59 & 66 & 1.7 \\
\hline Proline & 123 & 158 & 118 & 89 & 110 & 3.3 \\
\hline Serine & 81 & 85 & 86 & 65 & 85 & 1.5 \\
\hline Taurine & 0 & 0 & 0 & 104 & 90 & 8.5 \\
\hline Threonine & 67 & 51 & 77 & 78 & 85 & 2.2 \\
\hline Tyrosine & 97 & 135 & 97 & 86 & 103 & 2.2 \\
\hline Valine & 94 & 112 & 77 & 81 & 97 & 1.8 \\
\hline
\end{tabular}

fishmeal. *Cross referenced against protein (Nitrogen) digestibility from Table 4. 
Table 6. Literature raw material composition ( $\mathrm{g} \mathrm{kg}^{-1} \mathrm{DM}$ ) and digestibilities (\%)

\begin{tabular}{|c|c|c|c|c|c|c|c|c|c|}
\hline \multirow[b]{2}{*}{ Raw material } & \multicolumn{4}{|c|}{ Raw Material Composition } & \multicolumn{4}{|c|}{ Raw Material Digestibility } & \multirow[b]{2}{*}{ Published as } \\
\hline & Protein & Lipid & Ash & $\mathrm{CHO}$ & DM & Protein & Energy & Starch & \\
\hline Meat meal A & 581 & 110 & 339 & 0 & - & 54 & 58 & - & McMeniman, 1998 \\
\hline Meat meal B & 608 & 146 & 242 & 4 & - & 64 & 66 & - & “ \\
\hline Poultry offal meal & 658 & 145 & 178 & 20 & - & 79 & 77 & - & “ \\
\hline Fishmeal (Danish) & 760 & 114 & 130 & 0 & - & 88 & 83 & - & “ \\
\hline Fishmeal (Tuna meal) & 567 & 111 & 303 & 18 & - & 92 & 69 & - & “ \\
\hline Soybean meal (solvent-extracted) & 448 & 184 & 53 & 315 & - & 85 & 76 & - & “ \\
\hline Soybean meal (full-fat) & 530 & 16 & 73 & 381 & - & 86 & 69 & - & “ \\
\hline Peanut meal & 321 & 480 & 27 & 172 & - & 92 & 69 & - & “ \\
\hline Canola meal (solvent-extracted) & 409 & 30 & 68 & 492 & - & 81 & 56 & - & “ \\
\hline Lupin (L. angustifolius) kernel meal & 440 & 88 & 27 & 445 & - & 98 & 61 & - & “ \\
\hline Wheat gluten & 841 & 24 & 16 & 119 & - & 102 & 99 & - & “ \\
\hline Lupin (L. luteus cv. Wodjil) kernel meal & 567 & 67 & 39 & 327 & 65 & 81 & 83 & - & Glencross, 2011 \\
\hline Lupin (L. angustifolius cv. Myallie) kernel meal & 412 & 64 & 35 & 489 & 37 & 96 & 73 & - & “ \\
\hline Yellow lupin protein concentrate & 819 & 112 & 29 & 40 & 92 & 99 & 113 & - & “ \\
\hline Narrowleaf lupin protein concentrate & 754 & 153 & 23 & 70 & 89 & 86 & 100 & - & “ \\
\hline Soybean meal (solvent extracted) & 500 & 17 & 86 & 397 & 57 & 103 & 65 & - & “ \\
\hline Canola meal (expeller extracted) & 388 & 133 & 53 & 559 & 21 & 63 & 60 & - & $"$ \\
\hline Poultry offal meal & 608 & 119 & 160 & 113 & 10 & 40 & 52 & - & “ \\
\hline Hydrolysed feather meal & 802 & 144 & 17 & 37 & 37 & 75 & 68 & - & “ \\
\hline Barley (871) & 269 & 81 & 28 & 622 & 50 & 63 & 56 & 96 & Glencross et al., 2012 \\
\hline Barley (Waxiro) & 184 & 41 & 19 & 756 & 59 & 94 & 63 & 57 & “ \\
\hline Barley (Torrens) & 252 & 36 & 24 & 687 & 85 & 79 & 77 & 41 & “ \\
\hline Wheat & 196 & 31 & 15 & 758 & 66 & 100 & 65 & 30 & “ \\
\hline
\end{tabular}




\begin{tabular}{|c|c|c|c|c|c|c|c|c|c|}
\hline Oats & 135 & 91 & 25 & 749 & 58 & 98 & 52 & 55 & $“$ \\
\hline Barley & 151 & 44 & 21 & 784 & 47 & 153 & 55 & 46 & $"$ \\
\hline Sorghum & 138 & 39 & 15 & 808 & 56 & 110 & 54 & 18 & $"$ \\
\hline Tapioca & 7 & 3 & 4 & 986 & 74 & - & 58 & 19 & $“$ \\
\hline Triticale & 205 & 26 & 20 & 749 & 64 & 111 & 57 & 37 & $“$ \\
\hline Corn & 52 & 26 & 18 & 905 & 81 & 150 & 43 & 18 & $"$ \\
\hline Faba & 380 & 63 & 36 & 521 & 65 & 104 & 62 & 41 & $"$ \\
\hline Lupin (L. albus cv. Kiev mutant) kernel meal & 502 & 82 & 37 & 379 & 58 & 102 & 68 & - & Tabrett et al., 2012 \\
\hline Lupin (L. albus cv. Andromeda) kernel meal & 482 & 86 & 37 & 395 & 75 & 109 & 79 & - & “ \\
\hline Lupin (L. albus cv. WALAB2014) kernel meal & 488 & 82 & 38 & 392 & 62 & 105 & 75 & - & “ \\
\hline Lupin (L. angustifolius cv. Myallie) kernel meal & 383 & 54 & 34 & 529 & 41 & 97 & 51 & - & $“$ \\
\hline Fishmeal (Anchovetta) & 721 & 85 & 158 & 36 & 92 & 93 & 95 & - & Glencross et al., 2014 \\
\hline Pregelled Wheat Starch & 10 & 1 & 3 & 986 & 84 & - & 86 & - & “ \\
\hline Vitamin Free Casein & 811 & 1 & 13 & 175 & 85 & 100 & 87 & - & “ \\
\hline Wheat Gluten & 710 & 46 & 8 & 236 & 90 & 100 & 98 & - & $“$ \\
\hline Canola meal SE (Footscray) & 370 & 57 & 67 & 506 & 55 & 82 & 66 & - & Diu et al., 2015 \\
\hline Canola meal SE (Newcastle) & 423 & 44 & 69 & 464 & 59 & 84 & 71 & - & “ \\
\hline Canola meal SE (Nurmurkah) & 381 & 56 & 78 & 485 & 58 & 84 & 68 & - & “ \\
\hline Canola meal EX (Pinjarra) & 348 & 92 & 70 & 490 & 56 & 80 & 68 & - & $“$ \\
\hline Lupin (L. angustifolius cv. Coromup) kernel meal & 408 & 64 & 31 & 497 & 58 & 86 & 71 & - & “ \\
\hline
\end{tabular}

ADM, Decatur, IL, USA.; Alfaone, Condell Park, NSW, Australia; BEC Feed Solutions, Carole Park, QLD, Australia; CSIRO Plant Industries, Black Mountain, ACT, Australia; COGGO, Winthrop, WA, Australia; Coorow Seed Cleaners, Coorow, WA, Australia; Manildra, Auburn, NSW, Australia; Ridley Aquafeeds, Narangba, QLD, Australia; Skretting Australia, Cambridge, TAS, Australia . SE: Solvent extracted. EX: Expeller extracted. 
